\title{
PRDSES PENGEMBALIAN KERUGIAN NEGARA AKIBAT TINDAK PIDANA KDRUPSI (Studi di Kejaksaan Negeri Medan)
}

\author{
Lesson Sihotang' , Elsa Marlina Simalanga ${ }^{2}$ \\ Fakultas Hukum Universitas HKBP Nommensen, Medan \\ sihotangmarsait78国gmail.com
}

\author{
Info Artikel \\ Diterima : 20 April 202I \\ Revisi : ZZ Mei 2021 \\ Terbit : : 28 Juni 2021

\section{Key wards:} \\ Loss State, Corruption
}

\section{Kata Kunci:}

Kerugian, Negara, Koгupsi

\section{Corresponding Author :}

Lessan Sihatang

Email:

sihotangmarsait78回gmail.com

Abstract

To find out the process of recovering state losses in cases of corruption, and to find out the role of the prosecutor in the process of implementing state losses in cases of corruption as well as the obstacles to the process of recovering state losses due to corruption. And using the field method (field research), namely qualitative research by conducting direct research in the field to find out the existing problems through direet interviews with parties related to this research to obtain complete and accurate data. This results of the research that have been carried out are that the role of the Prosecutar in the implementation of returning state financial losses due to corruption through two instruments, the first is a criminal instrument, the second is a civil instrument. The implementation of the return of state losses due to corruption is carried out in a way, namely the Prosecutar's Dffice issues an order far the implementation of the decision (P48) to саггу out the court's decision. Then the Prosecutar's Office reports each execution of the warrant in the Minutes of the Implementation of the Judge's Determination (BA-15). After completion, the Prosecutar's Dffice will send a letter of Implementation of the Determination of the Panel of Judges to the Head of the State Detention Center.

\section{Abstrak}

Untuk mengetahui proses pengembalian kerugian negara dalam kasus tindak pidana korupsi, dan untuk mengetahui peranan jaksa dalam proses pelaksanaan pengembalian kerugian negara dalam kasus tindak pidana karupsi serta hambatanhambatan proses pengembalian kerugian negara akibat tindak pidana korupsi. menggunakan metode lapangan (fie/d research) yaitu penelitian secara kualitatif dengan mengadakan penelitian secara langsung kelapangan untuk mengetahui permasalahan yang ada melalui wawancara langsung dengan pihak-pihak yang berhubungan dengan penelitian ini untuk memperoleh data-data yang lengkap dan akurat. Hasil penelitian yang telah dilakukan yaitu bahwa Peranan Jaksa dalam pelaksanaan pengembalian kerugian keuangan negara akibat tindak pidana korupsi melalui dua intrumen, pertama intrumen pidana, kedua instrumen perdata. Pelaksanaan pengembalian kerugian negara akibat tindak pidana korupsi dilakukan dengan cara, yaitu Kejaksaan mengeluarkan surat perintah pelaksanaan putusan (P48) untuk melaksanakan perintah putusan pengadilan. Kemudian Kejaksaan melaparkan setiap pelaksanan surat perintah tersebut dalam Вerita Асага Pelaksanaan Penetapan Hakim (BA-15). Setelah selesai Kejaksaan akan mengrimkan surat Pelaksanaan Penetapan Majeli Hakim kepada Kepala Rumah Tahanan Negara. 


\section{PENDAHULLUAN}

Pada dasarnya dalam suatu negara yang berdasar atas hukum (rechtstaat) mewajibkan masyarakatnya untuk taat pada apa yang diatur dalam hukumnya masing-masing, namun di Indonesia hal tersebut masih jauh dari harapan bahkan hukum terkadang dijadikan sebagai alat bagi penguasa untuk melindungi kepentingannya serta menjustifikasi suatu tindakan yang jelas-jelas bertentangan dengan ketentutan hukum yang berlaku. Keuangan negara merupakan inti sari dalam pembangunan dan perekonomian suatu negara,

Hak ekonomi yang dijamin oleh konstitusi atau UUD 1945, adalah yang berkaitan dengan hak pekerja dan penghidupan yang layak. Hak ini berkaitan juga dengan kebijakan perekonomian, perlindungan fakir miskin, kesejahteraan lahir batin bagi rakyat, hak memperoleh pendidikan dan sebagainya. Tidak terpenuhnya hak-hak ini anatara lain karena semakin merebaknya praktik korupsi dalam berbagai sektor kehidupan masyarakat.' Kerugian keuangan negara berkaitan dengan pasal 2 ayat (I) dan pasal 3 UU PTPK yang menyebutkan bahwa salah satu yang harus dipenuhi dalam mengungkapkan terjadinya tindak pidana karupsi adalah dapat merugikan keuangan negara atau perekonamian negara. Hal-hal yang dapat merugikan keuangan negara antara lain: ${ }^{2}$

a. Perbuatan manusia, perbuatan yang sengaja dan tidak disengaja seperti karena kelalaian, kealpaan, kesalahan atau ketidakmampuan, serta pengawasan terhadap penggunaan keuangan negara yang tidak memadai

b. Kerugian keuangan negara karena adanya pengguntingan uang (sinering), gejolak moneter yang mengakibatkan turunnya nilai uang sehingga menaikan jumlah kewajiban negara.

Pengembalian kerugian negara dilakukan melalui berbagai instrumen salah satunya melalui instrumen pidana dengan cara penjatuhan membayar uang pengganti, cara ini bertujuan untuk memisahkan terpidana korupsi (koruptor), karena jumlah kerugian negara yang dikorupsi harus diganti, apalagi jika dijatuhi pidana denda sehingga harta terpidana akan terkuras selain dari harta yang dikorupsi. Namun dalam pasal I8 ayat (3) Undang-Undang Pemberantasan Tindak Pidana Karupsi, memberikan toleransi bahwa jika terpidana tidak mempunyai harta benda yang mencukupi untuk membayar uang pengganti maka dipidana dengan pidana penjara yang lamanya tidak melebihi ancaman maksimum dari pidana pokoknya, dan pidana tersebut sudah ditentukan dalam putusan pengadilan. Seperti putusan Nomor 04/Pid.Sus-TPK/2019/PN Mdn ${ }^{3}$

Masalah korupsi bukan lagi masalah baru dalam persaalan hukum dan ekonomi bagi suatu negara. Korupsi telah menyerap dan menyelinap dalam berbagai bentuk, atau modus operandi sehingga menggerogati keuangan negara, pereknnamian negara dan merugikan kepentingan masyarakat. ${ }^{4}$ Dalam menangani kasus

\footnotetext{
'Rudi Pardede, Prases Pengembalian Kerugian Negara Akibat Tindak Pidana Korupsi, Genta, Pekanbaru, 2015 hImll3

${ }^{2}$ bbid. hlm I0S

${ }^{3}$ Direktari Putusan Mahkama Agung Republik Indanesi Pengadilan Negeri Medan

${ }^{4}$ Rudi Pardede, Karupsi Di Inonesia Masalah dan Pencegahannya. Gramedia Pustaka Ltama, Jakarta, I991, hlm 2
}

Prases Pengembalian Kerugian Negara Akibat Tindak Pidana Karupsi (Studi Di Kejaksaan Negeri Medan) 
korupsi Indanesia lebih cenderung mengutamakan pada penghukuman terhadap pelaku tindak pidana korupsi dari pada pengembalian kerugian negara. ${ }^{5}$ Hal tersebut dterlihat dalam pidana subsidair yang selama ini tidak mengandung ukuran yang konsisten antara satu perkara dengan perkara lain, sehingga disparitas yang lebar berpatensi menimbulkan pilihan bagi terpidana untuk memilih tambahan pidana ketimbang mengembalikan uang negara yang dikarupsi. ${ }^{6}$

Disparasi ${ }^{7}$ yang terjadi di Indanesia memperlihatkan bahwa penjatuhan denda dalam jumlah besar tidak serta merta diikuti dengan penjara pengganti dalam kurung waktu yang sepadan dengan nilai denda. Begitu pula sebaliknya, jika denda yang dijatuhkan cukup besar namun pidana penjara pengganti yang ditetapkan tidak seimbang, bahkan lebih kecil dari putusan yang lain.

Beberapa contoh putusan Tindak Pidana Korupsi yang menunjukkan ketidak sebandingan antara denda dengan pidana subsidair yang dijalani, seperti terlihat pada tabel di bawah ini:

Tabel I. Ketidaksebandingan Denda dengan Pidana Pengganti Kurungan

\begin{tabular}{|c|c|c|c|}
\hline ND. & PUTUSAN & DENDA & PIDANA PENGGANTI \\
\hline 1. & $\begin{array}{l}\text { Nomar 04/Pid.Sus- } \\
\text { TPK/2DIG/PN.Mdn }\end{array}$ & Rp 50.000.000,- & 3 bulan \\
\hline 2. & $\begin{array}{l}\text { Nomar 05/Pid.Sus- } \\
\text { TPK/2017/PN.Mdn }\end{array}$ & Rp 50.000.000,- & 3 bulan \\
\hline 3. & $\begin{array}{c}\text { Nomar } \\
\text { 02/Pid.Sus.TPK/ZDI7/PN.Md } \\
\pi \\
\end{array}$ & Rp 50.०००.०००,- & 2 bulan \\
\hline 4. & $\begin{array}{l}\text { Nomar 1//Pid.Sus- } \\
\text { TPK/2017/PN.Mdn }\end{array}$ & Rp 50.000.000,- & I bulan \\
\hline 5. & $\begin{array}{l}\text { Nomar 04/Pid.Sus- } \\
\text { TPK/20IG/PN Mdn }\end{array}$ & Rp 200.000.000,- & I bulan \\
\hline 6. & $\begin{array}{c}\text { Namar 07/Pid.Sus- } \\
\text { TPK/PN>Mdn }\end{array}$ & Rp 50.०००.०००,- & 2 bulan \\
\hline
\end{tabular}

Sumber. Direktori Putusan Mahkama Agung Republik Indanesi Pengadilan Negeri Medan.

Berkaitan dengan tabel diatas, terlihat adanya ketidak sebandingan antara denda dengan pidana subsidair yang dijalani. Akibat tersebut berdampak terdahap keuangan negara dimana denda yang seharusnya dibayar dapat digantikan dengan pidana pengganti berupa penjara maupun kurungan. Persaalannya negara akan tetap membiaya terpidana sampai hukuman terpidana selesai dilaksanakan. Dalam keadaan ini keuangan negara

\footnotetext{
${ }^{5}$ Abd Razak Musahib, "Pengembalian Keuangan Negara Hasil Tindak Pidana Korups", Volume 3 Nomar I, Januari 2015 hlm 3

${ }^{8}$ Ade Mahmud, "Prablematika Asset Recavery dalam Pengembalian Kerugian Negara" Volume II Nomar 3, Desember 2018 hlm 363 ${ }^{7}$ https://m.hukumonline.com, diakses tgl 20 Desember 2DIG 
yang seharusnya bertambah dari denda yang telah jatuhkan justru menghabiskan lebih banyak biaya untuk menjalankan hukuman yang telah dijatuhkan kepada terpidana.

Dalam perspektif hukum pidana, tindak pidana karupsi tergolong sebagai bentuk kejahatan yang sangat berbahaya, baik terhadap masayarakat maupun bangsa dan negara. Kerugian keuangan negara dan perekanamian negara adalah akibat nyata yang menjadi dasar pembenaran dilakukannya kriminalisasi terhadap bentuk korupsi dalam kebijakan perundang-undangan pidana ${ }^{8}$

\section{METODE PENELITIAN}

Ruang lingkup penelitian dalam penelitian ini adalah: peranan jaksa dalam proses pelaksanaan pengembalian kerugian negara akibat tindak pidana korupsi dan faktor-faktor penghambat proses pelaksanaan pengembalian kerugian negara akibat tindak pidana korupsi .

\section{Metade Penelitian}

Metade penelitian yang digunakan dalam penelitian ini adalah metode secara kualitatif yang dilakukan untuk mengumpulkan data dengan cara studi lapangan (fie/d research) di Kejaksaan Negeri Medan. Yang dilakukan dengan cara wawancara dengan Jaksa Aristomy Siahaan selaku Kasubsi Uheksi. Dan juga melihat pada Undang-Undang RI Nomor 3l Tahun 1999 jo. Undang-Undang RI Nomor 20 Tahun 200I Tentang Perubahan atas Undang-Undang RI Nomor 3̆l Tahun 1999 Tentang Pemberantasan Tindak Pidana Korupsi.

\section{Analisis Bahan Hukum}

Metode analisis data yang digunakan dalam penelitian ini adalah analisis sasiologis yuridis yang digunakan dalam upaya yang bersifat preventif dengan cara menguraikan, membahas, menafsir, temuan-temuan penelitian dengan sudut pandang tertentu baik yang disajikan dalam bentuk narasi untuk data kualitatif maupun dalam bentuk tabel untuk data kuantitatif. Data yang diperaleh dari penelitian kemudian dianalisa secara deskriptif kuatitatif, yaitu mengelompokkan data-data yang diperoleh, yang kemudian dihubungkan dengan masalah yang akan diteliti kebenarannya., kemudian diuraikan sehingga diperaleh gambaran dan penjelasan tentang kebenaran yang sebenarnya, guna menjawab permasalahan.

\section{HASIL DAN PEMBAHASAN}

Peranan Jaksa Dalam Pelaksanaan Pengembalian Kerugian Keuangan Negara Akibat Tindak Pidana Korupsi (Studi di Kejaksaan Negeri Medan)

\footnotetext{
${ }^{8}$ H. Elwi Danil, Karupsi KansepTindak Pidana Dan Pemberantasannya, Raja Grafinda Persada, Jakarta 2012 
Lembaga Kejaksaan Republik Indonesia diatur dalam Undang-Undang Republik Indanesia Nomar I6 tahun 2004 tentang Kejaksaan Republik Indanesia. Aturan ini menjadi dasar hukum pelaksanaan tugas dan sebagai penyidik serta penuntut umum. Penuntut Umum adalah jaksa yang diberi wewenang untuk melakukan penuntutan dan melaksanakan penetapan hakim. Sedangkan Jaksa adalah pejabat fungsional yang diberi wewenang untuk bertindak sebagai penuntut umum dan pelaksana putusan pengadilan yang telah memperaleh kekuatan hukum tetap serta wewenang lain berdasarkan undang-undang. ${ }^{9}$

Kejaksaan Rl yang merupakan lembaga pemerintah yang melaksanakan kekuasaan negara dibidang penuntutan harus bebas dari kekuasaan politik manapun. Dalam penuntutan dilaksanakan secara terbuka terlepas dari pengaruh kekuasaan pemerintah dan pengaruh dan kekuasaan lainnya. Kejaksaan sebagai penegak hukum dituntut lebih berperan dalam menegakkan supremasi hukum, perlindungan kepentingan umum, penegakan hak asasi manusia (HAM), serta pemberantasan korupsi. [Debagai perkara pidana, penanganan korupsi dilakukan oleh penyidik, penuntut umum dan hakim yang terangkai dalam apa yang disebut dengan Sistem Peradilan Pidana. Namun demikian dilihat dari sisi hukum acara pidana memiliki kekhususan-kekhususan tertentu".

Lembaga Kejaksaan Negeri Medan memiliki struktur organisasi yang terdiri dari: ${ }^{12}$

\section{Bagan Struktur Drganisasi Kejaksaan Negeri Medan}

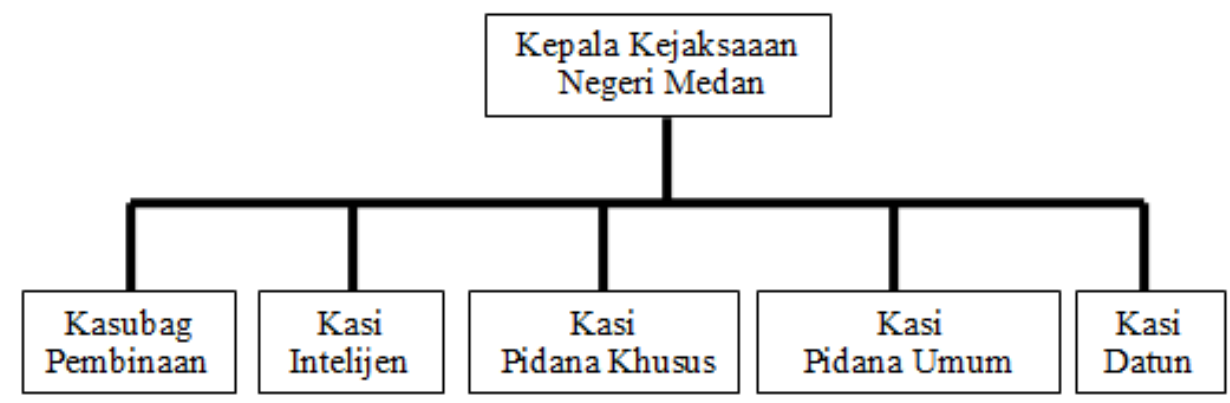

\footnotetext{
${ }^{9}$ Undang-Undang No. I6 tahun 2004 tentang Kejaksaan Republik Indanesia

10 Diponegara Low Jaurnal, Dp.cit, hlm 5, Lihat juga, Evi Hartati, Tindak Pidana Karupsi, Sinar Grafika, Jakarta, 2006, hlm 5

"Andi Muhammad Sadyan, Amiruddin, "Uang Pengganti Sebagai Alternatif Pengembalian Kerugian Negara Dalam Perkara Tindak Pidana Karupsi" Jurnal Restorative Justice, Vol. Z, No. I, hlm 55

${ }^{12}$ Andi Muhammad Sadyan, Amiruddin, , 2018 "Uang Pengganti Sebagai Alternatif Pengembalian Kerugian Negara Dalam Perkara Tindak Pidana Korupsi" Jurnal Restarative Justice, Vol. 2, No. I, hlm 55
} 


\section{Bagan Struktur Drganisasi Tindak Pidana Khusus Kejaksaan Negeri Medan}

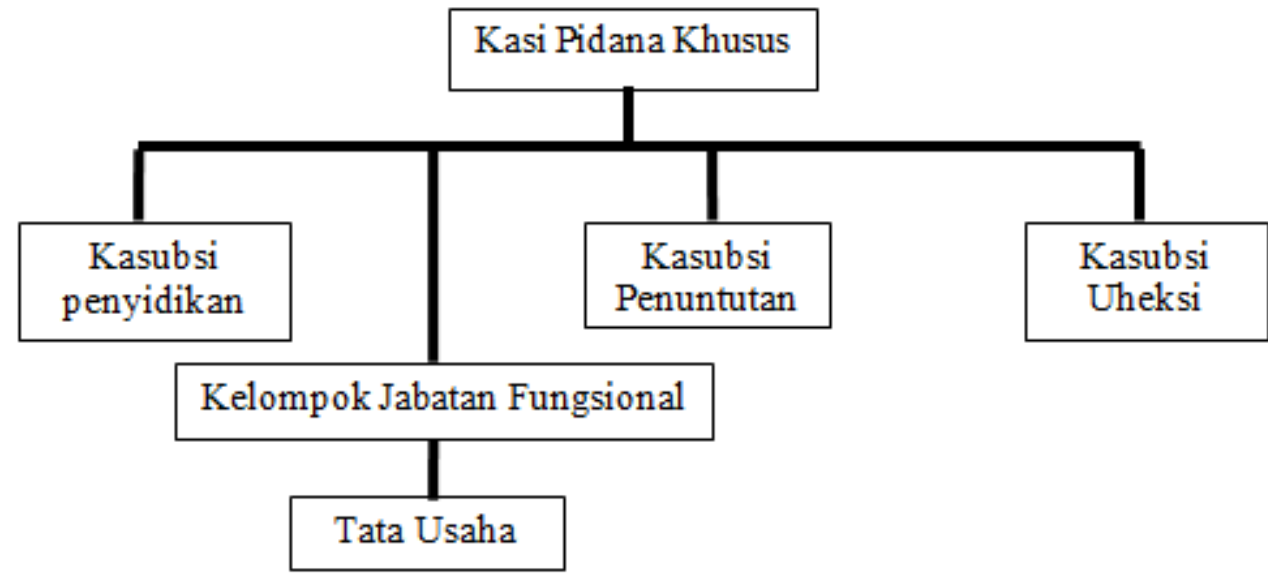

Bagan Struktur Organisasi Perdata dan Tata Usaha Negara Kejaksaan Negeri Medan

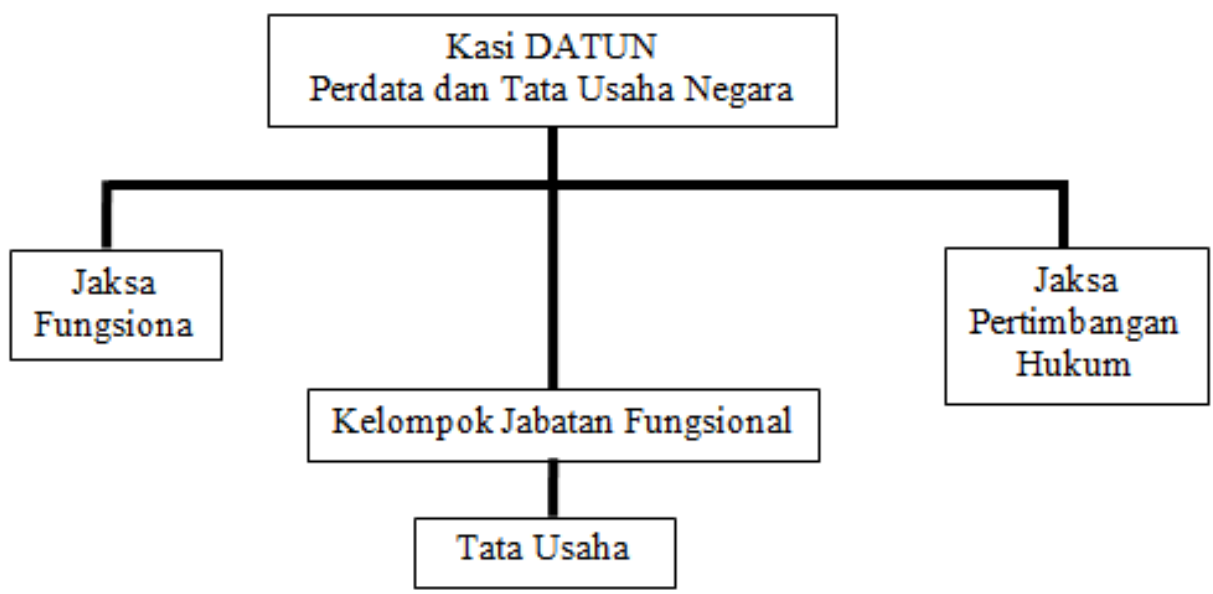

Berdasarkan bagan diatas, terlihat struktur organisi Kejaksaan Negeri Medan, yang terdiri dari berbagai sub-sub seperti bagan struktur diatas. Pada Kejaksaan Negeri Medan badan yang bertugas dalam melakukan proses pengembalian kerugian negara adalah:

a. Melalui intrumen perdata, pengembalian kerugian negara berdasarkan pasal 32, pasal 33, pasal 34 dan pasal 380

b. Melalui instrumen Pidana, Jaksa yang diberi tugas dan wewenang dalam melakukan eksekusi putusan pengadilan negeri adalah Kasubsi Uheksi.

Jaksa Penuntut Umum dan Jaksa Pengacara negara memiliki tugas dan wewenang berdasarkan Undang-Undang Nomor 30 tahun 2004 tentang Kejaksaan

I. Melakukan pengelolaan laporan dan pengaduan masyarakat 
2. Penyelidikan

3. Penyidikan

4. Pelacakan aset dan pengelolaan barang bukti

5. Prapenuntutan

6. Pemeriksaan tambahan

7. Praperadilan

8. Penuntutan dan persidangan,

9. Perlawanan

10. Upaya hukum

II. Pelaksanaan penetapan hakim dan putusan pengadilan yang telah mempunyai kekuatan hukum tetap pengawasan terhadap pelaksanaan pemidanaan bersyarat, putusan pidana pengawasan, keputusan lepas bersyarat, dan eksaminasidalam penanganan perkara tindak pidana khusus di wilayah hukum Kejaksaan Negeri.

Dalam rangka menyelesaikan kerugian negara, dibentuk Tim Penyelesaian Kerugian Negara (TPKN) yang diangkat oleh pimpinan instansi, yang selanjutnya akan menindaklanjuti setiap kasus kerugian negara berdasarkan laporan dari bendahara atau kepala satuan kerja kepada pimpinan instansi. Pimpinan instansi kemudian menyampaikan laparan hasil verifikasi kerugian negara kepada Badan Pemeriksan Keuangan (BPK), maka BPK akan melakukan pemeriksaan atas laparan kerugian negara untuk menyimpulkan telah terjadi kerugian negara yang meliputi nilai kerugian negara, perbuatan melawan hukum baik sengaja maupun lalai, dan penanggungjawab. Kemudian BPK mengeluarkan surat kepada instansi untuk memproses kerugian negara melalui Surat Keterangan Tanggung Jawab Mutlak (SKTJM).

Berdasarkan penelitian yang telah dilakukan oleh peneliti di Kejaksaan Negeri Medan tepatnya pada bagian pidana khusus, Peneliti memperoleh data tentang kasus-kaus korupsi yang telah ditangani oleh kejaksaan dan telah mempunyai kekuatan hukum tetap (incraht) selama tiga tahun terakhir, serta pengembalian kerugian negara, yang dimuat dalam bentuk tabel dibawah ini.

Tabel I. Kasus-Kasus Tindak Pidana Korupsi yang ditangani Dleh Kejaksaan Negeri Medan Tahun 2019 Sampai Dengan Maret 202I

\begin{tabular}{|c|c|c|l|}
\hline No. & Tahun & $\begin{array}{c}\text { Kasus Korupsi yang ditangani } \\
\text { Kejaksaan Negeri Medan }\end{array}$ & \multicolumn{1}{c|}{ Jenis Kasus Korupsi } \\
\hline I. & 2019 & 73 & $\begin{array}{l}\text { - Perbuatan curang } \\
\text { - Pemerasan } \\
\text { - Gratifikasi, }\end{array}$ \\
\hline
\end{tabular}


ISSN (print) : 2722-7316

e-ISSN : 2723-1275

https://ejournal.uhn.ac.id/index.php/humaniora/

\begin{tabular}{|c|c|c|c|}
\hline & & & $\begin{array}{l}\text { - Suap menyuap } \\
\text { - Penggelapan dalam jabatan }\end{array}$ \\
\hline 2. & 2020 & 69 & $\begin{array}{l}\text { - Perbuatan curang } \\
\text { - Pemerasan } \\
\text { - Gratifikasi } \\
\text { - Suap menyuap } \\
\text { - Penggelapan dalam jabatan }\end{array}$ \\
\hline 3. & 2021 & 1 & Penggelapan dalam jabatan \\
\hline
\end{tabular}

Sumber Data: Kejaksaan Negeri Medan

Tabel 2. Tindak Pidana Korupsi Yang ditangani Dleh Kejaksaan Negeri Medan Yang Telah Mempunyai Kekuatan Hukum Tetap Tahun 2019 Sampai Dengan Maret 2021

\begin{tabular}{|c|c|c|c|}
\hline No. & Tahun & $\begin{array}{l}\text { Kasus Korupsi Yang Telah } \\
\text { Berkekuatan Hukum Tetap }\end{array}$ & Jenis Kasus Korupsi \\
\hline 1. & 2019 & 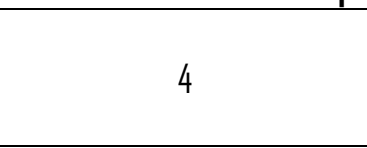 & $\begin{array}{l}\text { - Penggelapan dalam jabatan } \\
\text { - Gratifikasi } \\
\text { - Pemerasan }\end{array}$ \\
\hline 2. & 2020 & 3 & $\begin{array}{l}\text { - Pemerasan } \\
\text { - Gratifikasi } \\
\text { - Penggelapan dalam jabatan }\end{array}$ \\
\hline 3. & 2021 & 1 & Perbuatan curang \\
\hline \multicolumn{4}{|c|}{ Jumlah $\quad 8$} \\
\hline
\end{tabular}

Sumber Data: Kejaksaan Negeri Medan

Tabel 3. Tindak Pidana Korupsi Yang Mengembalikan Kerugian Negara Tahun 2019 Sampai Dengan Maret 2021

\begin{tabular}{|c|c|c|}
\hline Tahun & $\begin{array}{c}\text { Kasus Korupsi Yang mengembalikan Kerugian } \\
\text { Negara }\end{array}$ & Jenis Kasus Korupsi \\
\hline 2019 & 1 & Penggelapan dalam jabatan \\
\hline
\end{tabular}

Sumber Data: Kejaksaan Negeri Medan

Berdasarkan tabel tindak pidana korupsi tersebut diatas, dapat dijelaskan beberapa hal sebagai berikut:

I. Tabel I

Berdasarkan tabel I dapat dijelaskan beberapa hal sebagai berikut:

a. Kasus tindak pidana korupsi di Kejaksaan Negeri Medan dari tahun 2019 sampai Maret 202I menurun;

b. Kasus korupsi yang ditangani Kejaksaan Negeri Medan dari tahun 2019 hingga Maret 2021 bentuk pemerasan, perbuatan curang, suap menyuap, dan gratifikasi.

2. Tabel 2 
a. Kasus tindak pidana korupsi yang telah berkekuatan hukum tetap dari tahun 2019 sampai maret 2021 sebnayak 8 kasus saja

b. Kasus tindak pidana karupsi yang ditangani oleh Kejaksaan Negeri Medan yang mempunyai kekuatan hukum tetap (incraht) selama tiga tahun terakhir tidak sebanding banyaknya dengan kasus-kasus korupsi yang ditangani oleh Kejaksaan Negeri Medan

3. Tabel 3

a. Kasus tindak pidana korupsi yang mengembalikan kerugian negara dalam tiga tahun terakhir dimulai dari tahun 2019 sampai maret 2021 hanya ada pada satu kasus saja yaitu pada putusan No. 53/Pid.Sus;TPK/国回/PN Mdn.

b. Terlihat pengembalian kerugian negara belum berjalan dengan baik sesuai dengan tujuannya.

Terkait pengembalian kerugian keuangan negara, tentunya tidak terlepas dari berapa banyak kerugian negara yang timbul akibat tindak pidana karupsi sebagaimana data yang telah diuraikan diatas. Dari jumlah kasus yang ditangani oleh Kejaksaan Negeri Medan hingga saat ini baru I (satu) yang sudah berkekuatan hukum tetap (incraht) yang mengembalikan kerugian keuangan negara. Pengembalian yang dilakukan dalam kasus tersebut tidak sebanding dengan kerugian keuangan yang dialami negara.

Ada 3 (tiga) hal yang perlu kita ketahui dalam tindak pidana korupsi, yaitu peranan jaksa dalam penanganan tindak pidana korupsi, proses pengembalian kerugian negara akibat tindak pidana korupsi dan pelaksanaan pengembalian kerugian keuangan negara akibat tindak pidana korupsi.

a. Peranan Jaksa Dalam Penanganan Tindak Pidana Korupsi

Sejalan dengan kerugian negara akibat tindak pidana korupsi, peranan jaksa sangat penting dalam penanganan pengembalian kerugian tersebut. Jaksa Penuntut Umum dan Jaksa Pengacara negara memiliki perana yang sama. Adapun peranan jaksa dalam penanganan tindak pidana korupsi dilakukan dengan beberapa tahapan, yaitu pelacakan, pemblakiran, penyitaan, perampasan, serta pengembalian kerugian negara.

\section{Pelacakan}

Pelacakan atau penelusuran adalah tahapan awal untuk mengumpulkan dan mengidentifikasi datadata yang berhubungan dengan harta kekayaan hasil tindak pidana karupsi yang disembunyikan oleh pelaku agar tidak dapat ditemukan, dihitung jumlahnya, dan agar tidak dapat dilakukan penyitaan. Sehingga dilakukan pelacakan terhadap harta kekayaan tersebut. Pelacakan dapat dimulai saat proses penyelidikan dalam mencari unsur-unsur tindak pidana, pada saat penyidikan 
untuk mencari tersangkanya dan harta kekayaan hasil korupsi. ada tiga tahapan dalam melakukan pelacakan,yaitu tahapan perncanaan, pelaksaan dan pelaporan

\section{Pemblakiran}

Tahapan selanjutnya adalah tahapan pemblakiran atau pembekuan. Tujuan pemblakiran ini untuk mencegah harta kekayaan hasil tindak pidana dialihkan kepada orang lain. Undang-undang Nomor I tahun 2006 tentang Bantuan Timbal Balik Dalam Masalah Pidana pasal I ayat 6 merumuskan pemblokiran adalah pembekuan sementara harta kekayaan untuk kepentingan penyidik, penuntutan, atau pemeriksaan di sidang pengadilan dengan tujuan untuk mencegah dialihkan atau dipindahtangankan agar orang tertentu atau semua orang tidak berurusan dengan harta kekayaan yang telah diperoleh atau mungkin telah dipreoleh dari dilakukannya tindak pidana tersebut.tahap pemblakiran ini dapat dilakukan setelah hasil dari tahap pelacakan menemukan dugaan yang cukup mengenai asal usul harta kekayaan tersebut dari hasil tindak pidana korupsi.

\section{Penyitaan}

Tahap penyitaan adalah langkah antisipasi yang bertujuan meyelamatkan atau mencegah hilangnya harta kekayaan hasil korupsi. Harta kekayaan inilah yang kelak diputuskan pengadilan, apakah diambil sebagai upaya untuk mengembalikan kerugian negara atau sebagai pidana tambahan berupa merampas harta kekayaan hasil tindak pidana korupsi. Tahap penyitaan ini dilakukan saat harta kekayaan hasil korupsi telah ditemukan keberadaannya dan penyitaan dilakukan oleh penyidik. Pasal 38 Undang-Undang №. 8 Tahun 198 I Tentang Hukum Acara Pidana yang selanjut lebih dikenal dengan KUHP menerangkan bahwa Penyitaan hanya dapat dilakukan oleh penyidik dengan surat izin dari ketua pengadilan negeri setempat. Namun adapun pengecualian dalam keadaan mendesak penyidik harus segera bertindak dan tidak mungkin mendapatkan surat izin terlebih dahulu, maka penyidik dapat melakukan penyitaan hanya atas benda bergerak untuk itu wajib melaporkan kepada ketua pengadilan negeri setempat guna memperoleh persetujuannya.

\section{Perampasan}

Pada tahap ini dilakukan perampasan harta kekayaan hasil tindak pidana korupsi yang dijadikan upaya pengambilalihan hak dimana hasil kejahatan dirampas untuk negara atau hak atas keberadaannya sudah beralih kepada negara. kejaksaan yang telah ditunjuk sebagai lembaga yang melakukan perampasan akan menyelidiki harta kekayaan milik terpidana korupsi. perampasa ini dilakukan saat penyitaan peralihan atas benda atau hak atas benda belum sepenuhnya terjadi. 
5. Pengembalian kerugian negara

Berbicara mengenai pengembalian kerugian keuangan negara, tentu saja dilandaskan pada prinsip dasar "berikan kepada negara apa yang menjadi hak negara" dan berikan kepada rakyat apa yang menjadi hak rakyat". Kedua prinsip ini memberikan tanggungjawab kepada negara penerima aset hasil tindak pidana korupsi untuk mengembalikan aset tersebut kepada negara. Pasal 18 ayat (I) Undang-Undang Nomor 3l tahun 1999 Ja Undang-Undang Namar 20 tahun 2001 tentang Pemberantasan Tindak Pidana Korupsi telah memberikan solusi terhadap pengembalian kerugian keuangan negara, yakni perampasan, pembayaran uang pengganti, penutupan perusahaan, dan pencabutan hak. Dan dalam ayat (2) menegaskan bahwa "harta bendanya dapat disita dan dilelang" artinya jaksa diberi wewenang untuk menyita dan meelelang harta milik terdakwa sebagai pengembalian aset negara. Ayat (3) mengatakan bahwa dalam hal terpidana tidak mempunyai harta benda yang mencukupi untuk mengganti uang pengganti maka terpidana dipidana penjara yang lamanya tidak melebihi ancaman maksimum pidana pokaknya.

Berdasarkan penjelasan diatas menjadi jelas bahwa penjatuhan uang pengganti adalah upaya negara untuk mengambil dan menguasai kembali harta milik negara yang diambil oleh terpidana korupsi. Penjatuhan uang pengganti ini ditentukan oleh hakim dan akan dilaksanakan oleh jaksa yang menangani kasus tersebut. Apabila terpidana tidak membayar uang pengganti dalam waktu I (satu) bulan sesudah putusan pengadilan yang telah memperoleh kekuatan hukm tetap maka harta benda terpidana dapat disita oleh jaksa dan dilelang untuk menutupi uang pengganti tersebut.

b. Prases Pengembalian Kerugian Negara Akibat Tindak Pidana Karupsi

Berkenaan dengan pengembalian kerugian keuangan negara, tentunya perlu mengetahui berapa kerugian yang timbul akibat tindak pidana karupsi tersebut, dengan demikian dilakukan penghitungan kerugian negara. Penghitungan kerugian negara dilakukan oleh Badan Pemeriksa Keuangan (BPK) sebagaimana yang tercantum dalam pasal 10 Undang-Undang Nomor 15 tahun 2006 tentang Badan Pemeriksaan Keuangan. Setelah mengetahi kerugian negara kejaksaan akan melakukan peyelidikan terhadap harta kekayaan terpidana untuk disita dan dirampas.

Dari hasil wawawncara dengan Kasubsi Uheksi bapak Aristomy Siahaan mengatakan proses pengembalian kerugian negara dilakukan dengan dua cara, yaitu: ${ }^{13}$

\footnotetext{
${ }^{13}$ Wawancara dengan Jaksa Aristomy Siahaan, selaku Kasubsi Uheksi, pada tanggal 08 Maret 2021 
I. Terpidana memberikan uang pengganti atau denda sebagai pengembalian kerugian negara hasil tindak pidana korupsi kepada Kejaksaan. Kemudian Jaksa yang ditunjuk untuk melakukan pengiriman (Bendahara) akan meminta resi atau bukti bahwa terpidana telah mengembalikan kerugian negara tersebut. Setelah itu Bendahara akan mengembalikan uang hasil tindak pidana korupsi kepada negara, dengan menggunakan pengiriman melalui buku rekening kejaksaan.

2. Cara yang kedua ini hampir sama dengan cara pertama hanya saja terpidana tidak langsung memberikan harta kekayaan hasil karupsi terpidana. Melainkan dilakukan penyitaan dan perampasan terhadap harta kekayaan terpidana. Apabila harta kekayaan hasil tindak pidana karupsi telah disita dan dirampas, maka harta kekayaan tersebut akan dilelang dan hasil lelang tersebut akan dikembalikan kepada negara sebagai bentuk pengembalian kerugian negara.

Berbeda dengan Pengacara Negara yang sering disebut Datun, Upaya Jaksa Pengacara Negara dalam pengembalian keuangan negara akibat tindak pidana korupsi mempersipakan bukti formil dan dalil-dalil yang dikenal sebagai beban pembuktian, guna mencapai tujuan pengembalian kerugian keuangan negara maka Jaksa Pengacara Negara harus membuktikan bahwa secara nyata telah ada kerugian keuangan negara, kerugian keuangan negara sebagai akibat atau berkaitan dengan perbuatan terdakwa, adanya harta benda milik terdakwa yang digunakan untuk mengembalikan kerugian keuangan negara.

\section{c. Pelaksanaan Pengembalian Kerugian Keuangan Negara Akibat Tindak Pidana Korupsi}

Pelaksanaan pengembalian kerugian negara akibat tindak pidana karupsi dilakukan dengan dua aspek, yaitu pidana dan pidanaperdata.Melalui aspek pidana pengembalian kerugian negara akibat tindak pidana karupsi yang telah diputus oleh pengadilan dilakukan dengan cara:

I. Kejaksaan akan mengeluarkan surat perintah pelaksanaan putusan pengadilan (P48) yang akan menerangkan bahwa jaksa wajib melaksanakan perintah yang terdapat dalam putusan pengadilan negeri dengan penuh rasa tanggungjawab. Setelah surat perintah pelaksanaan putusan pengadilan dikeluarkan jaksa akan melaksanakan perintah tersebut sesuai dengan putusan pengadilan. Dalam hal pengembalian kerugian negara jaksa melaksanakan perintah putusan pengadilan, yaitu melakukan penglelangan terhadap barang sitaan milik terpidana kemudian hasil lelang tersebut diberikan kembali kepada negara sebagai pengembalian kerugian negara akibat tindak pidana karupsi.

2. Kejaksaan akan melaporkan setiap pelaksanaan surat peritah tersebut dengan Berita Acara Pelaksanaan Penetapan Hakim (BA-15) 
3. Kejaksaan mengelurkan surat Pelaksanaan Penetapan Majelis Hakim yang ditujukan kepada Kepala Rumah Tahanan Negara

Pengaturan gugatan perdata dalam Undang-Undang Tindak Pidana Korupsi didasarkan alasan-alasan sebagai berikut:

a. Penyelesaian perkara korupsi secara pidana tidak selalu berhasil mengembalikan kerugian keuangan negara, setidak-tidaknya dalam keadaan-keadaan tertentu.

b. Tindak pidana korupsi sebagai kejahatan yang luar biasa, yang melibatkan kekuasaan dan kerugian negara maka cara penanganannya dilakukan dengan cara yang luar biasa pula, yaitu disamping melalui jalur pidana juga dilakukan melalui jalur perdata.

c. Tujuan pengaturan gugatan perdata dimaksudkan untuk memenuhi rasa keadilan masyarakat terhadap pelaku tindak pidana korupsi yang menyembunyikan hasil karupsi maka diatur gugatan perdata untuk memaksimalkan pengembalian keuangan negara

Pengacara negara perlu memperbanyak gugatan secara perdata kalau syarat-syarat untuk melakukan gugatan perdata memang sudah cukup terpenuhi. Gugatan yang dilakukan jaksa sebagai pengacara negara tentunya tidak sekedar hanya untuk memenuhi unsur menggugat, akan tetapi juga harus memenuhi syarat formil dan materil. Dalam Undang-Undang Nomor 31 Tahun 1999 jo. Undang-Undang Nomor 20 Tahun 2001 telah diatur pula kemungkinan penggunaan gugatan perdata, yakni dalam Pasal 32, Pasal 33, Pasal 34 dan Pasal 38 huruf c, dalam hal terdakwa atau tersangka meninggal dunia atau tidak bisa dilanjutkannya penuntutan karena tidak cukup bukti meskipun sudah terdapat kerugian negara.

Dari hasil wawancara yang peneliti lakukan di Kejaksaan Negeri Medan, peneliti membuat bagan terkait proses pengembalian kerugian keuangan negara akibat tindak pidana korupsi. Dimana Jaksa berperan sebagai lembaga yang merampas dan menyita harta kekayaan hasil tindak pidana karupsi yang merugikan negara yang selanjutnya diatur dalam Undang-Undang №. I6 tahun 2004 tentang Kejaksaan Republik Indanesia. Adapaun bagan tersebut adalah sebagai berikut:

\section{Bagan I. Proses Pengembalian Kerugian Negara Berdasarkan Hasil Wawancara di Kejaksaan Negeri} Medan

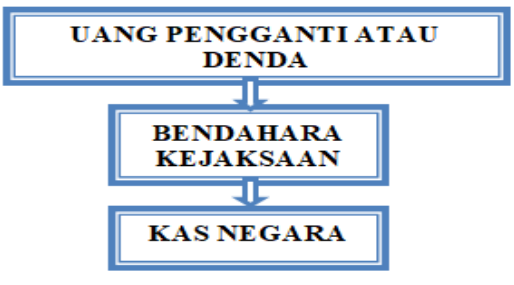


Pada bagan I ini uang pengganti atau denda yang telah diberikan terpidana, berdasarkan pasal 270 KUHAP menjelaskan bahwa pelaksanaan putusan pengadilan yang tetah memperoleh kekuatan hukum tetap dilakukan oleh jaksa, dan panitera mengirimkan salinan surat keputusan kepada jaksa. Pasal ini menyiratkan bahwa Jaksa dalam melakukan eksekusi harus berdasarkan pada bunyi amar putusan yang tercantum di dalam berkas putusan. Lama waktu tidak ditentukan dengan jelas. Namun pada prakteknya pengembalian kerugian melalui uang pengganti atau denda setelah puusan majelis hakim berkekuatan hukum tetap dan panitera mengirimkan salinan putusan serta terpidana telah memberikan uang pengganti atau denda, maka jaksa akan langsung mengirimkan uang tersebut ke kas negara.

\section{Bagan II. Proses Pengembalian Kerugian Negara Berdasarkan Hasil Wawancara di Kejaksaan Negeri Medan}

\section{HARTA KEKAY AAN HASIL KORUPSI}

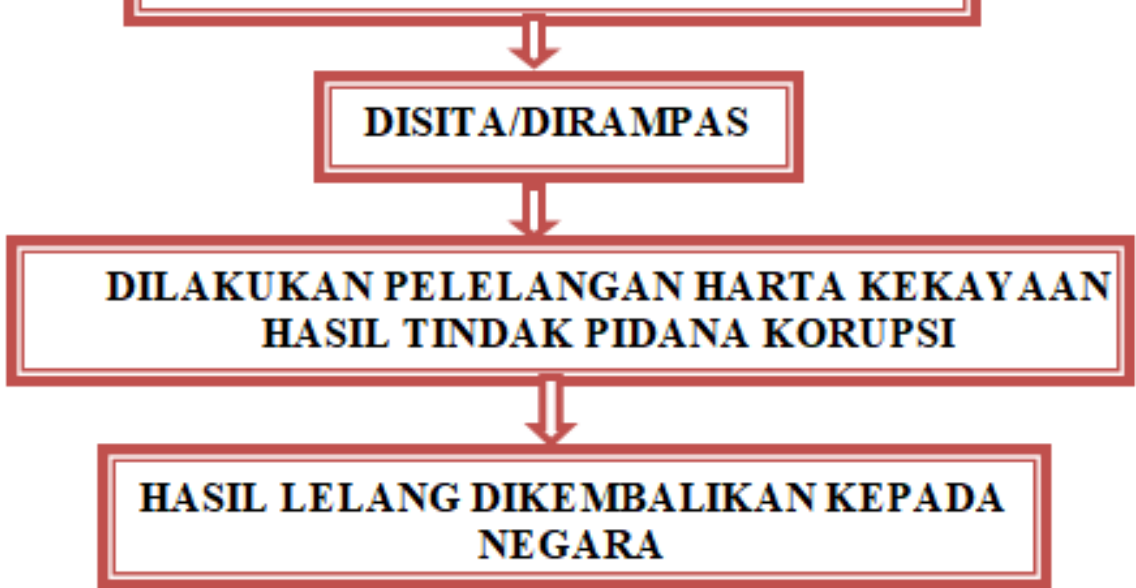

Pada bagan kedua ini, proses pengembaliannya dilakukan berdasarkan pelelangan barang rampasan dan benda sitaan milik terpidana. Peraturan Jaksa Agung RI PER-002/A/JA/D5/2017 tentang Pelelangan dan Penjualan Langsung Benda Sitaan atau Barang Rampasan Negara atau Benda Sita Eksekusi yang berisi tentang pengaturan lelang terhadap aset yang menjadi kewenangan kejaksaan namun mempunyai kondisi tertentu. Peraturan Jaksa Agung RI PER-Q0Z/A/JA/05/2017 ditujukan untuk memindahkan beban tanggungjawab dari kejakasaan kepada kantor lelang (KPKNL). KPKNL adalah lembaga pelelang milik negara yang berwenang melaksanakan lelang eksekusi. PMK Nomar 13/PMK.06/2018 merupakan peraturan mentri keuangan tentang Lelang Benda Sitaan, Barang Rampasan Negara atau Benda Sita Eksekusi yang berasal dari Kejaksaan. Peraturan ini bersifat lex specialis deragat legi generalis. 


\section{Faktor-Faktor Penghambat Pelaksanaan Pengembalian Kerugian Negara Akibat Tindak Pidana Korupsi}

Dalam melakukan penyidikan kasus korupsi, salah satu tujuannya adalah untuk menyelamatkan aset negara. Sampai saat ini, tindak pidana korupsi masih merupakan salah satu tindak pidana yang berbahaya dan sangat merugikan. ${ }^{14}$ Sehingga sejalan dengan itu, pemerintah selalu berupaya untuk menunjukan keseriusan untuk memberantasnya. Salah satu bentuknya adalah dengan mewujudkan keseriusan pemerintah dalam upaya bagaimana mengembalikan keuangan negara yang telah hilang karena dikørupsi.

Pelaksanaan pengembalian kerugian keuangan negara dilakukan oleh jaksa sebagaimana yang telah dijelaskan sebelumnya. Jaksa berwenang menyita dan merapas harta kekayaan hasil tindak pidana korupsi sebagai pengembalian kerugian negara. pada tahap pelaksanaan pengembalian kerugian keuangan negara tersebut tentuntunya tidak telepas dari hambatan-hambatan baik internal maupun eksternal. Dari hasil wawancara dengan Kasubsi Uheksi bapak Aristomy Siahaan mengatakan beberapa hambatan-hambatan yang dialami dalam pelaksanaan pengembalian kerugian negara akibat tindak pidaan korupsi, yaitu:

I. Pelaksanaan pada tahap Terpidana memberikan uang sebagai pengembalian kerugian negara, pada tahap ini beberapa hambatan yang dialami dalam pelaksanaannya, yaitu:

a. Kurangnya kejujuran terpidana dalam melaporkan harta kekayaan milik terpidana kepada komisi pemberantasan tindak pidana korupsi (KPK) atau Kejaksaan sehingga proses pengembalikan kerugian negara tidak maksimal.

b. Belum ada pengaturan yang jelas tentang sistem pengembalian kerugian keuangan negara.

2. Pelaksanaan pada tahap penyitaan dan perampasan terhadap harta kekayaan terpidana, pada tahap ini beberapa hambatan yang dialami dalam pelaksanaannya, yaitu:

a. Faktor utama yang dialami kejaksaan dalam pelaksanaan pengembalian kerugian keuangan negara adalah faktor eknnomi. Dimana terdakwa tidak sanggup membayar kerugian keuangan negara, dan saat dilakukan penyitaan sering terjadi barang yang akan disita telah dijual pada pihak lain dan telah digunakan untuk kehidupan sehari-hari. Sehingga sulit untuk melakukan penyitaan dan permpasan harta kekayaan hasil tindak pidan korupsi.

b. Kurangnya kerjasama dalam penangan kasus-kasus karupsi yang membuat sulit untuk menemuka harta kekayaan hasil korupsi.

c. Belum ada pengaturan yang jelas tentang sistem pengembalian kerugian keuangan negara.

${ }^{14}$ Rustam, Jurnal Dimensi, Pelaksanaan Pengembalian Kerugian Kuangan Negara (Asset Revavery) Dalam Tindak Pidana Karupsi, Volume 6, Nomar 2:206-225, Agustus 2017, hlm 213 
d. Terpidana meninggal dunia, saat pengembalian kerugian negara terpidana meninggal dunia sehingga pelaksanaan pengembalian kerugian negara terhambat, sedangkan ahli waris yang akan dituntut melalui gugatan perdata tidak mempunyai harta benda peninggalan terpidana.

e. Sering terjadi konflik anatara keluarga terpidana dengan pihak kejaksaan, dimana pihak keluarga tidak ingin harta kekayaannya disita dan dirampas untuk negara.

Berdasarkan penjelasan diatas dimana yang merupakan hasil wawanvara yang dilakukan penulis di Kejaksaan Negeri Mendan tepatnya pada Kasubsi Uheksi bapak Aristamy Siahaan dalam melakukan peroses pelaksanaan pengembalian kerugia negara akibat tindak pidana korupsi tidak terlepas dari hambatan-hambatan baik dari diri terpidana, masyarakat maupun lembaga kejaksaan itu sendiri.

\section{KESIMPLLAN}

\section{Kesimpulan}

Berdasarkan hasil penelitian dan pembahasan yang telah diuraikan atas, penulis menarik beberapa kesimpulan bahwa:

1. Peranan Jaksa dalam pelaksanaan pengembalian kerugian keuangan negara akibat tindak pidana korupsi melalui dua intrumen, pertama intrumen pidana, kedua instrumen perdata. Pelaksanaan pengembalian kerugian keuangan negara akibat tindak pidana korupsi dilakukandengan beberapa tahapan, yaitu: pelacakan, pemblokiran, penyitaan, perampasan, serta pengembalian kerugian negara. Pelaksanaan pengembalian kerugian negara akibat tindak pidana korupsi dilakukan dengan cara, yaitu Kejaksaan mengeluarkan surat perintah pelaksanaan putusan (P48) yang menugaskan Kasubsi Uheksi untuk melaksanakan perintah putusan pengadilan. Kemudian Kejaksaan melaporkan setiap pelaksanan surat perintah tersebut dalam Berita Acara Pelaksanaan Penetapan Hakim (BA-15). Setelah selesai Kejaksaan akan mengrimkan surat Pelaksanaan Penetapan Majeli Hakim kepada Kepala Rumah Tahanan Negara.

2. Dalam proses pengembalian kerugian negara Kejaksaan Negeri Medan memiliki hambatan-hambatan baik internal maupun eksternal. Adapun yang menjadi kendala atau faktor dalam pelaksanaan pengembalin kerugian negara adalah faktor ekonomi, ketidak jujuran terpidana, tidak adanya pengaturan yang jelas, terpidana meninggal dunia dan faktor dari keluarga terpidana. 


\section{Saran}

Setelah penulis menarik beberapa kesimpulan, tentunya penulis juga akan memberikan beberapa saran terkait proses pengembalian kerugian negara akibat tindak pidana korupsi. Adapun saran tersebut adalah sebagai berikut:

I. Sebaiknya proses pengembalian kerugian negara akibat tindak pidana korupsi harus diatur dengan jalas dalam undang-undang. Perlu adannya optimalisasi tugas dan fungsi kejaksaan sebagai instansi yang mempunyai peran dalam pengembalian kerugian negara akibat tindak pidana korupsi supaya pengembalian kerugian negara akibat tindak pidana korupsi sesuai dengan kerugian negara.

2. Kejaksaan Negeri Medan perlu melakukan kerjasama yang baik antara penyidik Polri untuk memberantas tindak pidana korupsi dan mengembalikan yang menjadi hak negara.

\section{DAFTAR PUSTAKA}

Adys. Kadir Abdul, Anamali Karupsi Nampak Tilas Kessejahterahan, Yagyakarta: Suluh Media, 2018 Chazawi, Adami, Hukum Pidana Karupsi di Indanesia, Jakarta: Raja Persada, 2017

Danil, Elwi H, Karupsi Kansep Tindak Pidana Dan Pemberantasannya, Jakarta: RajaGrafinda Persada, 2012

Djaja, Ermansyah, Membetantas Karupsi Bersama KPK, Jakarta: Sinar Grafika 2009

Gunawan, T. J, Kansep Pemidanaan Berbasis Nilai Kerugian Ekonami, Jakarta Kencana, 29lם

Hamza, Andi Jur, Pemberantasan KarupsiMelalui Hukum Pidana Nasional Dan Internasional, Jakarta: Raja Grafindo Persada, 2008

Khalis, Laila Efi, Pembayaran Uang Pengganti Dalam Pertara Karupsi, Jakarta: Solusi Publishing: 2010

Marzuki, Mahmud Peter, Penelitian Hukum, Jakarta: Kencana, 2005

Pardede, Rudi, Proses Pengembalian Kerugian Negara Akibat Tindak Pidana Karupsi, Pekanbaru: Genta, 2015

Prodjahamidjojo, Penerapan Pembuktian Terbalik Dalam Delik Karupsi, Bandung: Mndar Maju, 200I

Prakosa, Djoku, Hukum Penitensi Di Indanesia, Yogyakarta: Liberty, 1988

Sumaryanta, Djokn A. Pembalikan Beban Pembuktian Tindak Pidana Dalam Rangka Pengembalian Kerugian Keuangan Negara, Jakart: Prestasi Pustaka Publisher, 2009

Tuanakntta, M. Thendurus, Menghitng Kerugian Keuangan Negara Dalam Tindak Pidana Korupsi Jakarta: Slembah Empat

\section{Peraturan Perundang-undangan}

Undang-Undang Nomor 31 Tahun 1999 jo Undang-Undang Nomor 20 Tahun 200I Tentang Pemberantasan Tindak Pidana Korupsi

Undang-Undang Nomar I6 Tahun 2014 Tentang Kejaksaan Republik Indanesia

Jurnal

Adb. Razakm Musahib, Pengembalian Kerugian Negara Hasil Tindak Pidana Karupsi, Volume 3, Nomor I, Januari 2015

Ade, Mahmud, Prablematika Asset Recavery Dalam Pengembalian Kerugian Negara, Volume I, Nomar , Desember 2018 
Puteri, Hikmawati, Pengembalian Kerugian Negara Dari Pembayaran Uang Pengganti Tindak Pidana Karupsi Dapatkah Dptima/, Volume I0 Nomor I, 2019

Michael, Julnius Cristapher Siahaya, Pengembalian Krugian Negara Dalm Tahap Penyidikan Tindak Pidana Korupsi, Volume IV, Nomor Z, 2018

Amty, Prakarsa, Renayulia, Madel Pengembalian Aset (Asset Recavery) Sebagai Alternatif Memulihkan Kerugian Negara Dalam Perkara Tindak Pidana Korupsi, Volume 6, Nomor I Tahun 2017

Andi Muhammad Sayan Amiuddin, Dptimalisasi Pengaturan Hukum Tentang Pengembalian Kerugian Keuangan Negara Dalam Kasus Tindak Pidana Korupsi, Volume 3 Nomar 2, 2019

Roby Azhari, Pengembalian Kerugian Keuangan Negara Akibat Tindak Pidana Karupsi, Volume 5, Nomor 2, 2018

Diponegaru Low Jurnal, Peranan Kejaksaan Dalam Upaya Pengembalian Kerugian Keuangan Negara Akibat Tindak Pidana Karupsi, Volume 5 Nomor 3, 20I6

Henra Karianga, Pertanggungjawaan Kerugian Negara Dalam Pengelalahan Keuangan Daerah, Volumen IG, Nomor 1, 2018

Candra, Ayu Astuti, Aris Cariri, Penentuan Kerugian Keuangan Negara Yang Dilakukan Dleh BPK Dalam Tindak Pidana Kaupsi, Volume 4, Nomor 32015

Supriyadi, Penetapan Tindak Pidana Sebagai Kejahatan Dan Pelanggaran Dalam Undang-Undang Pidana Khusus. Volume 27, Nomar 3, 2015

Septa Candra, Perumusan Ketentuan Pidana Dalam Peraturan Perundang-Undangan Di Indanesia, Volume 3. Nomar 3, 2013

Luh Rina Apriani, Penerapan Filsafat Pemidanaan Dalam Tindak Pidana Korupsi, Volume III, Nomar DI, 2010

Samuel Mangapul Tapubolon, Peranan Pemerintah Dalam Upaya Pemberantasan Karupsi Kaitannya Dengan Undang-Undang Nomar 32 Tahun 2004, Volume II, Nomor 6, 2014

Internet

https://m.hukumonline.com, diakses tgl 3 Desember 2016 